\title{
“Just Convict Everyone!" - Joint Perpetration: From Tadić to Stakić and Back Again
}

\author{
MOHAMED ELEWA BADAR*
}

Prosecutor v. Milomir Stakić: Judgment of the Appeals Chamber ${ }^{1}$

\section{Introduction}

On 22 March 2006, the Appeals Chamber of the International Criminal Tribunal for the Former Yugoslavia (ICTY) rendered its Judgment in the Stakić case. ${ }^{2}$ Dr. Milomir Stakić, the former President of the Prijedor Municipal Assembly, was found guilty and sentenced to life imprisonment by the Trial Chamber for his participation in the murder, extermination and persecution (incorporating deportation) of the non-Serb population in Prijedor. ${ }^{3}$ Both the Defence and the Prosecution filed appeals against the Trial Chamber's Judgment and Sentence. ${ }^{4}$ The Appeals Chamber affirmed the Trial

* Judge, Ministry of Justice, Egypt; Senior Prosecutor, Public Prosecution Office, (1997-2001). PhD cand. with a Doctoral thesis entitled 'Towards a Unified Concept for Mens Rea in International Criminal Law', The Irish Centre for Human Rights, National University of Ireland, Galway (2002-2006); LL.M. in International Human Rights, ICHR, NUI, Galway, 2001; LL.B. \& Bachelor of Police Sciences, Police Academy, Police College, Cairo, Egypt, 1991. The views expressed in this case note are exclusively those of the author.

${ }^{1}$ Prosecutor v. Milomir Stakić, Case No. IT-97-24-A, Appeals Judgment, 22 March 2006 (Stakić Appeals Judgment).

${ }^{2}$ Ibid.

${ }^{3}$ Prosecutor v Milomir Stakić, Case No. IT-97-24-T, Trial Judgment, 31 July 2003, Disposition, (Stakić Trial Judgment).

${ }^{4}$ The Appellant appealed on the grounds that the Trial Chamber allegedly: erred in law and fact by allowing an expansion of the Indictment; erred in law and fact during the course of the trial proceedings; erred in fact leading to a miscarriage of justice; erred in law and fact in the application of Article 5 of the Statute; erred in law and fact in the application of Article 3 of the Statute; erred in law and fact on the issue of sentencing; and erred in law and fact regarding cumulative convictions. The Prosecution appealed on the grounds that the Trial Chamber allegedly: erred in law in finding that the appellant did not have the requisite intent for genocide under Article 4 of the Statute; erred in law and/or fact in its consideration of Article 4(3)(c) of the Statute; erred in law in its conclusion that the Bosnian Croats did not form a group or part of a group targeted for genocide under Article 4 of the Statute; erred of law in failing to cumulatively convicted the Appellant on Counts 3 (murder as a crime against humanity) and 7 (deportation as a crime against humanity). In short, the first three Prosecution grounds were dismissed. 
Chamber's decision to convict Stakić for his responsibility in the aforementioned crimes. It also agreed with the Trial Chamber's decision to acquit Milomir Stakić of genocide and complicity in genocide. ${ }^{5}$ The Appeals Chamber, however, found that the Trial Chamber incorrectly failed to convict Stakic for deporting and forcibly transferring the non-Serb population. ${ }^{6}$ Based on an error made by the Trial Chamber regarding the sentence, the Appeals Chamber imposed a global sentence of 40 years' imprisonment on the Appellant. ${ }^{7}$

One of the issues which the Appeals Chamber addressed propio motu was the mode of liability attributed to the Appellant by the Trial Chamber. ${ }^{8}$ In examining the criminal responsibility of Dr. Milomir Stakic for the crimes alleged, the Trial Chamber applied a mode of liability which it termed 'coperpetratorship' (committing 'jointly with another person'), in lieu of 'joint criminal enterprise' (JCE). In so doing, the Stakic Trial Chamber avoided "the misleading impression that a new crime [membership in a criminal organization] not foreseen in the Statute of this Tribunal has been introduced through the backdoor." "However, "[t]he introduction of new modes of liability [co-perpetratorship] into the jurisprudence of the Tribunal", the Appeals Chamber stressed, "may generate uncertainty, if not confusion, in the determination of the law by parties to cases before the Tribunal as well as in the application of the law by Trial Chambers." 10

Most notably, some ICTY judges have welcomed and fully approved the JCE doctrine "as an effective tool for overcoming the problems of ascribing individual criminal responsibility for international crimes."11 Others hold the opinion that the concept of 'joint criminal enterprise', since its foundation and integration into the jurisprudence of the ICTY by the Tadić Appeals Chamber, "has caused confusion and a waste of time" 12 and has been considered as a

${ }^{5}$ Stakić Appeals Judgment, Disposition.

${ }^{6}$ Stakić Appeals Judgment, Disposition.

${ }^{7}$ Stakić Appeals Judgment, Disposition.

${ }^{8}$ Neither party has appealed the Trial Chamber's application of this mode of liability, notably, "co-perpetratorship".

${ }^{9}$ Stakić Trial Judgment, para. 441 (footnotes omitted). Unfortunately, the Stakić Trial Judgment did not make any effort to determine whether or not this concept, Mittäterschaft ("co-perpetratorship"), as it stands in German criminal law, may have reflected customary international law at the time the crimes at issue were committed. In footnote 949 of the Judgment, the Stakić Trial Chamber made references to two eminent common law scholars, but that was not sufficient to prove that this German concept may reflect customary international law.

${ }^{10}$ Stakić Appeals Judgment, para. 59.

${ }^{11}$ For a systematic analysis on the law of 'joint criminal enterprise' in the jurisprudence of the ICTY, see Verena Haan, 'The Development of the Concept of Joint Criminal Enterprise at the International Criminal Tribunal for the Former Yugoslavia', 5 International Criminal Law Review (2005) 167-201.

12 Prosecutor v Blagoje Simić et al., Case No. IT-95-9-T, Trial Judgment, 17 October 2003 (Simić Trial Chamber), Separate and Partly Opinion of Judge Per-Johan Lindholm, paras. 2-5. 
doctrine "of no benefit to the work of the Tribunal or the development of international criminal law." 13 This note will examine, therefore, both modes of liability ('joint criminal enterprise' and 'co-perpetratorship') in light of the Stakic Appeals and Trial Judgments.

\section{The Integration of 'Co-Perpetratorship' in the Case Law of the ICTY}

In its analysis of the responsibility of Dr. Milomir Stakić, the Trial Chamber explicitly rejected the application of 'joint criminal enterprise' as a mode of liability despite the fact that it had been pleaded by the Prosecution both in the indictment ${ }^{14}$ and at trial. ${ }^{15}$ The Stakic Trial Chamber holds the opinion that "joint criminal enterprise is only one of several interpretations of the term 'commission' under Article 7(1) of the Statute and that other definitions of co-perpetration must equally be taken into account." "A more direct reference to 'commission' in its traditional sense", according to the Stakić Trial Chamber, "should be given priority before considering responsibility under the judicial term 'joint criminal enterprise'."17

${ }^{13}$ Prosecutor v Blagoje Simić et al., Case No. IT-95-9-T, Trial Judgment, 17 October 2003 (Simić Trial Judgment) Separate and Partly Opinion of Judge Per-Johan Lindholm, paras. 2-5. The entire passage of Judge Lindholm reads as follows, "I dissociate myself from the concept or doctrine of joint criminal enterprise in this case as well as generally. The so-called basic form of joint criminal enterprise does not, in my opinion, have any substance of its own. It is nothing more than a new label affixed to a since well-known concept or doctrine in most jurisdictions as well as in international criminal law, namely co-perpetration. . . If something else than participation as co-perpetrator is intended to be covered by the concept of joint criminal enterprise, there seems to arise a conflict between the concept and the word 'committed' in Article 7(1) of the Statute.” Ibid., para, 2. In Krnojelać, the Trial Chamber declined to apply the second category of 'joint criminal enterprise' because in their view it did not comply with the principle of individual criminal responsibility, Prosecutor v. Milorad Krnojelać, Case No. IT-97-25-T, Trial Judgment, 15 March 2002, (Krnojelać Trial Judgment) para. 78.

${ }^{14}$ See the Prosecution Fourth Amended Indictment (Case No. IT-97-24-PT) para. 26: "Milomir STAKIĆ participated in the joint criminal enterprise, in his roles as set out . . a above. The purpose of the joint criminal enterprise was the permanent forcible removal of Bosnian Croat inhabitants from the territory of the planned Serbian state, including a campaign of persecutions through the commission of the crimes alleged in Counts 1 to 8 of the Indictment.

${ }^{15}$ Prosecution Final Trial Brief, para. 82, cited in Stakić Appeals Judgment, para. 58, fn. 138.

${ }^{16}$ Stakić Trial Judgment, para. 438. Article 7(1) of the ICTY Statute provides: "a person who planned, instigated, ordered, committed or otherwise aided and abetted in the planning, preparation or execution of a crime referred to in articles 2 to 5 of the present Statute, shall be individually responsible for the crime."

${ }^{17}$ Stakić Trial Judgment, para. 438. In Simić, Judge Per-Johan Lindholm upholds the same opinion, Simić Trial Judgment, Separate and Partly Opinion of Judge Per-Johan Lindholm, supra note 13 , para. 2 . 
The Stakić Judgment defined the word 'committed' under Article 7(1) of the ICTY Statute in the following words: "[T]he accused participated, physically or otherwise directly or indirectly, in the material elements of the crime charged through positive acts or, based on duty to act, omissions, whether individually or jointly with others. The accused himself need not have participated in all aspects of the alleged criminal conduct."18

Thus, in order to meet the requirements of 'co-perpetratorship' as a mode of liability, the Prosecution must prove beyond reasonable doubt that there was (i) an explicit agreement or silent consent between two or more individuals to reach a common goal; (ii) by coordinated co-operation; and (iii) joint control over the criminal conduct. ${ }^{19}$ The Stakić Judgment requires that the coperpetrators can only realize their plan insofar as they act jointly, but each individual can ruin the whole plan if he does not carry out his part. To this extent, each of the co-perpetrators is in control of the act. ${ }^{20}$ In order to clarify its position, the Judgment referred to Professor Claus Roxin's example: "[i]f two people govern a country together - are joint rulers in the literal sense of the word - the usual consequence is that the acts of each depend on the co-perpetration of the other. The reverse side of this is, inevitably, the fact that by refusing to participate, each person individually can frustrate the action." 21

In addition to the mens rea required for the specific crime charged, this mode of liability (co-perpetratorship) requires proof of (i) mutual awareness of substantial likelihood that crimes would occur; and (ii) the defendant's awareness of the importance of his own role. ${ }^{22}$ Applying this mode of liability to the facts of the present case, the Trial Chamber was convinced that: "Dr. Stakic knew that his role and authority as the leading politician in Prijedor was essential for the accomplishment of the common goal. He was aware that he could frustrate the objective of achieving a Serbian municipality by using his powers to hold to account those responsible for crimes, by protecting or assisting non Serbs or by stepping down from his superior position." 23

In view of the aforementioned, it is clear that the Trial Chamber understands the meaning of the word 'committing' under Article 7(1) of the ICTY-Statute in broader terms. Thus, "[b]y accepting the mutual attribution of contributions

${ }^{18}$ Stakić Trial Judgment, para. 439.

${ }^{19}$ Stakić Trial Judgment, para. 440.

${ }^{20}$ Stakić Trial Judgment, para. 440 quoting Claus Roxin, (Täterschaft und Tatherrschaft "Perpetration and Control Over the Act" (Berlin, New York, 1994) 278.

${ }^{21}$ Stakić Trial Judgment, para. 440 (footnotes omitted).

${ }^{22}$ Stakić Trial Judgment, paras. 495-497.

${ }^{23}$ Stakić Trial Judgment, para. 498. 
made in functional division of labour for the accomplishment of the crime, not only the person who physically kills the victim, but also the organizer of the plan and the provider of means can be held liable as co-perpetrators." ${ }^{24}$

On this particular point, the Stakić Trial Chamber applied "a combination of two forms of commission, known in German criminal law as Mittäterschaft ("coperpetration") and mittelbare Täterschaft ("perpetrator behind the direct perpetrator")." 25 This approach put an end to a long-lasting debate regarding the issue of whether participants who carried out criminal conducts which form no part of the actus reus of the offence but, nonetheless, have a decisive role in its commission may be considered co-perpetrators or mere accomplices. The following hypothetical case is illustrative on that matter. A, B, and C agree to destroy an ethnic group, $\mathrm{D}$, by poisoning the main water pipe which provides this group with their daily water. $\mathrm{C}$, the chemical expert, provides A and B with the sufficient amount of poison. A and B carry out the criminal conduct by adding the poison into the pipe. Is $\mathrm{C}$ a co-perpetrator or mere accomplice? Applying Stakic's co-perpetratorship approach to the present hypothetical example, $\mathrm{C}$ is considered a co-perpetrator and not a mere accomplice, so long as he satisfies the above mentioned requirements. ${ }^{26} \mathrm{C}$ 's appearance on the scene when the actus reus (criminal conduct) of offence was carried out is not required to consider him a co-perpetrator, according to the Stakić conception. ${ }^{27}$

However, one important question remains unresolved regarding this mode of liability as introduced by the Stakić Trial Chamber. Difficulties appear in cases where the definition or the character of an offence varies according to the intent or the knowledge possessed by one or more co-perpetrators with which the crime has been committed. The question which arises is whether the effect of such intent or knowledge shall extend to the other co-perpetrators concerned in the commission of the offence at issue. The following hypothetical example illustrates this. A, B, and C, high ranking officials in State $\mathrm{X}$, agreed to conduct a widespread and systematic campaign to exterminate all those who opposed their government policy. In carrying out this agreement, $\mathrm{C}$ had a further intent to conduct this campaign in order to destroy in whole or in part a religious group which also opposed State X's policy. Did A, and B commit the crime of

${ }^{24}$ Albin Eser, 'Individual Criminal Responsibility', in Antonio Cassese et al., (eds), I The Rome Statute of the International Criminal Court: A Commentary (Oxford: Oxford University Press, 2002) 767-822, at 790.

${ }^{25}$ Verena Haan, supra note 11, at 197.

${ }^{26}$ See supra notes 19, 20 and the accompanying text.

${ }^{27}$ Whether each co-perpetrator must necessarily be on the scene when the crime is accomplished or whether even a contribution in the preparatory stage may suffice are still disputed questions in German criminal law, see Albin Eser, supra note 24, at 791, fn. 95. 
genocide ${ }^{28}$ Surprisingly, according to the third category of 'joint criminal enterprise', ${ }^{29} \mathrm{~A}$ and B may be held criminally liable for the crime of genocide if it was a natural and foreseeable consequence of the execution of the initial criminal plan (extermination as a crime against humanity).

Despite the fact that the Stakic Trial Judgment limited itself to the clear wording of the Statute when interpreting 'committing' in the form of 'coperpetration', in lieu of joint criminal enterprise, the Appeals Chamber's recent Judgment marked the death of this mode of liability in the jurisprudence of the ICTY. The Appeals Chamber declared: "the Trial Chamber erred in conducting its analysis of the responsibility of the Appellant within the framework of 'co-perpetratorship'. This mode of liability . . . does not have support in customary international law . . . By contrast, joint criminal enterprise is a mode of liability which is firmly established in customary international law and is routinely applied in the Tribunal's jurisprudence." 30

\subsection{In the Appeals Chamber: Incorporating 'Co-Perpetratorship' in 'Joint Criminal Enterprise'}

In paragraph 62 of its judgment, the Stakić Appeals Chamber confirmed that the Trial Chamber decision as to the mode of liability it employed is invalidated, ${ }^{31}$ and the sole remedy is to apply the correct legal framework - joint criminal enterprise - to the factual conclusions of the Trial Chamber. ${ }^{32}$ In so doing, the Appeals Chamber confined itself to examine the first and third category of 'joint criminal enterprise' as understood from the plain language of the Indictment. ${ }^{33}$ In order to reach a decision as to whether the first and third

${ }^{28}$ The answer may be found in the very last sentence of Article 39(2) of the Egyptian Penal Code. Article 39 provides: "A person is concerned as a principal in the commission of an offence:

(1) Who commits such offence whether alone or in conjunction with others; or

(2) Who in the case of an offence consisting of two or more acts, knowingly participates in such offence by doing one or more of such acts.

Provided that where circumstances personal to any principal are such as to modify with respect to such principal either the character of the offence or the penalty, the effect of such circumstances shall not extend to other principles concerned in the commission of the offence. The like rule shall apply when the character of the offence varies according to the intent or the knowledge with which it has been committed."

${ }^{29}$ See Section 2.1 .3 of the present case note.

${ }^{30}$ Stakić Appeals Judgment, para. 62 (footnotes omitted).

${ }^{31}$ Stakić Appeals Judgment, para. 62.

32 Stakić Appeals Judgment, para. 63.

${ }^{33}$ Stakić Appeals Judgment, para. 66. In paragraph 26 of the Indictment, the Prosecution alleged that the purpose of the joint criminal enterprise was a campaign of persecutions that encompassed the crimes alleged in counts 1 through 8 of the Indictment. The Appeals Chamber found that, in this paragapgh, the Prosecution was plainly alleging a basic joint criminal eneterprise - the crimes alleged were within the common purpose. In paragraphs 28 and 29 of the Indictment, however, the Prosecution set out an alternative theory: 
categories of 'joint criminal enterprise' may be fitting of the factual findings of the Stakic Trial Judgment, the Appeals Chamber conducted a three tiered test.

\subsubsection{Did the Appellant Participate in a 'Joint Criminal Enterprise'?}

In determining whether the Trial Chamber's factual findings show that the Appellant bears the basic (or first) category 'joint criminal enterprise' liability for the crimes encompassed by the criminal purpose, the Appeals Chamber found:

"[t]he common goal identified by the Trial Chamber amounted to a common purpose within the meaning of the Tribunal's joint criminal enterprise doctrine. This common purpose consisted of a discriminatory campaign to ethnically cleanse the Municipality of Prijedor by deporting and persecuting Bosnian Muslims and Bosnian Croats in order to establish Serbian control ("Common Purpose"). . . . The campaign consisted of criminal acts prescribed in the Statute of this Tribunal, notably the crimes against humanity of persecutions, deportation and other inhumane acts. . .." 34

Convinced that the Trial Chamber's factual findings supported the conclusion that the Appellant had participated in a joint criminal enterprise as mentioned above, the Appeals Chamber went on to examine the following question.

\subsubsection{Did the Appellant Intend to further the 'Common Purpose' of the Joint Criminal Enterprise?}

In examining the relevant passages of the Trial Judgment regarding the present query, the Appeals Chamber found that various findings of the Trial Chamber demonstrate the existence of a shared intent among the participants

Para. 28: "Aternatively, the accused is individually responsible for the crimes enumerated in Counts 1 to 8 on the basis that these crimes were natural and foreseeable consequences of the execution of the common purpose of the joint criminal enterprise and Milomir STAKIĆ was aware that these crimes were the possible consequence of the execution of the joint criminal enterprise."

Para. 29: "Despite his awareness of the possible consequences, Milomir STAKIĆ knowingly and wilfully participated in the joint criminal eneterprise. On this basis, he bears individual criminal responsibility for these crimes under Article 7(1) in addition to his responsibility under the same article having planned, instigated, ordered or otherwise aided and abetted in the planing, preparaition, or execution of these crimes." (emphasis in original).

${ }^{34}$ Stakić Appeals Judgment, para. 75 (emphasis are in original). According to the Tadic Appeal Chamber, the basic category of joint criminal enterprise requires proof that the accused shared the intent specifically necessary for the concrete offence and voluntarily participated in that enterprise, see Prosecutor v. Duško Tadić, Case No. IT-94-1-A, Appeals Judgment, 15 July 1999 (Tadić Appeals Judgment) paras. 190-206. 
in the joint criminal enterprise. ${ }^{35}$ One passage of the Trial Chamber's findings which is obviously based on Professor Claus Roxin's theory of 'joint control over the act' was incorporated by the Appeals Chamber into the realm of joint criminal enterprise of the first category. This paragraph reads as follows: "[t]he Trial Chamber is convinced that Dr. Stakić knew that his role and authority as the leading politician in Prijedor was essential for the accomplishment of the common goal. He was aware that he could frustrate the objective of achieving a Serbian municipality by using his powers to hold to account those responsible for crimes, by protecting or assisting non-Serbs or by stepping down from his superior positions." ${ }^{\text {36 }}$

Applying the legal framework of joint criminal enterprise to the factual findings, the Appeals Chamber concluded that there was a 'joint criminal enterprise' of the first category operating in the Municipality of Prijedor and that the Appellant was (i) a participant in that joint criminal enterprise; (ii) made a substantial contribution to the implantation of the common purpose; and (iii) shared the intent to further it. ${ }^{37}$

Having established the existence of first category joint criminal enterprise liability for persecution, deportation, and other inhuman acts (forcible transfer) on the part of the Appellant, the Appeals Chamber turned to the remaining question of whether the factual findings of the Trial Chamber also support a finding of third category joint criminal enterprise liability for certain crimes. ${ }^{38}$

\subsubsection{Does the Appellant Incur Third Category Joint Criminal Enterprise Liability for Certain Crimes Falling Outside the Scope of the Enterprise?}

According to the Stakić Appeals Judgment, for the application of third category joint criminal enterprise liability, the following elements must be established: "(a) crimes outside the Common Purpose have occurred; (b) these crimes were a natural and foreseeable consequence of effecting the Common Purpose; and (c) the participant in the joint criminal enterprise was aware that the crimes were a possible consequence of the execution of the Common Purpose, and in that awareness, he nevertheless acted in furtherance of the Common Purpose." 39

${ }^{35}$ Stakić Appeals Judgment, para. 80.

${ }^{36}$ Stakić Trial Judgment, para. 498 quoted by Stakić Appeals Judgment, para. 82.

${ }^{37}$ Stakić Appeals Judgment, para. 85.

${ }^{38}$ The remaining crimes for which the Appellant was found criminally responsible by the Trial Chamber under the 'co-perpetration' concept were murder as a war crime and crimes against humanity and the crime of extermination.

${ }^{39}$ Stakić Appeals Judgment, para. 87 (capital letters are in original). 
At this stage, the Appeals Chamber had to evaluate the factual findings of the Trial Judgment in order to reach a conclusion as to whether these findings demonstrate that the Appellant had the requisite mens rea to be found responsible under the third category of 'joint criminal enterprise' for the crimes of murder (as a war crimes and as a crime against humanity) and extermination. ${ }^{40}$ In so doing, the Appeals Chamber concluded that the Trial Chamber's factual findings "demonstrate that the Appellant had the requisite mens rea to be found responsible under the third category of joint criminal enterprise ... [for the foregoing crimes]." ${ }^{41}$

\section{Conclusion}

A major source of concern with regard to the applicability of JCE III in the sphere of international criminal law is that under both the objective and subjective standards, the participant is unfairly held liable for criminal conducts that he neither intended nor participated in. It is also unjust that the liability of the actual perpetrator (the one who carried out the crime outside the common plan) is tested subjectively whereas that of the participant is tested objectively. Moreover, if the accused had actually participated in crimes outside the initial plan 'common purpose' as an aider or abettor they would arguably have an increased chance of acquittal, as the Prosecution would be confronted with having to prove a higher level of mental awareness, namely, that the accused knew that the principal perpetrator had the state of mind required for the crime at issue. ${ }^{42}$ Finally, and more dramatically, this extended category of JCE serves to convict the participant in a common plan for crimes carried out by the actual perpetrator even if the former lacks the state of mind or the mens rea required for the crime in question (particularly specific purpose crimes). ${ }^{43}$

${ }^{40}$ While examining the modes of participation pursuant to Articles 7(1) and 7(3) of the ICTY Statute and particularly the three categories of joint criminal enterprise under which Stakic was charged the Trial Chamber noted with special reference to the mens rea of joint criminal enterprise that "Article 7(1) lists modes of liability only. These can not change or replace elements of crimes defined in the Statute. In particular, the mens rea elements required for an offence listed in the Statute cannot be altered." Stakić Trial Judgment, para. 437.

${ }^{41}$ Stakić Appeals Judgment, para. 98.

42 See Tadić Appeals Judgment, para. 229.

${ }^{43}$ For a critical views with regard to the applicability of the third category of 'joint criminal enterprise' see Marco Sassòli and Laura M. Olson, 'The judgment of the ICTY Appeals Chambr on the merits in the Tadic case', International Review of the Red Cross No. 839 (2000) 739-769. 
Today many crimes within the jurisdiction of the International Criminal Tribunal for the former Yugoslavia fall within the ambit of JCE III: the most recent was extermination as a crime against humanity. ${ }^{44}$ One serious problem that will soon confront the Yugoslavia Tribunal is the applicability of JCE III to specific purpose crimes, notably torture, genocide, persecution, and the crime of terror against the civilian population. ${ }^{45}$ It is questionable whether individuals should be convicted of such high profile and morally culpable crimes, on the basis of mere foresight. Addressing this point, the Stakic Trial Chamber spelled out its concerns in the following words, "the application of a mode of liability can not replace a core element of a crime. The Prosecution confuses modes of liability and the crimes themselves. Conflating the third variant of joint criminal enterprise and the crime of genocide would result in the dolus specialis being so watered down that it is extinguished." 46

If, one day, the Prosecution succeeds in granting a conviction for one of the 'specific purpose crimes' under the third category of joint criminal enterprise, this will alter the JCE doctrine to become an umbrella to 'just convict everyone'. ${ }^{47}$

${ }^{44}$ Stakić Appeals Judgment, para. 98.

${ }^{45}$ See Mohamed Elewa Badar, 'Drawing the Boundaries of Mens Rea in the Jurisprudence of the International Criminal Tribunal for the Former Yugoslavia', 6/3 International Criminal Law Review (2006) (forthcoming).

${ }^{46}$ Stakić Trial Judgment, para. 530. See also Prosecutor v. Radoslav Barđanin, Decision on Motion for Acquittal Pursuant to Rule 98 bis, Case No. IT-99-36-T, Trial Chamber Decision, 28 November 2003, para. 57 ("This specific intent [of genocide] cannot be reconciled with the mens rea for a conviction pursuant to the third category of JCE. The latter consists of the accused's awareness of the risk that genocide would be committed by other members of the JCE. This is a different mens rea and falls short of the threshold needed to satisfy the specific intent required for a conviction for genocide under Article 4(3)(a).") Most notably, this finding by the Trial Chamber was overturned by the Appeals Chamber in Prosecutor v. Radoslav Barđanin, Decision on Interlocutory Appeal, Case No. IT-99-36-A, Appeals Chamber Decision, 19 March 2004.

${ }^{47}$ The term "just convict everyone" was used by Professor William Schabas as an alternative to the third category of JCE during a lecture at the 5th Annual 'International Criminal Court-Summer Course', Galway, 2005. 
Copyright of International Criminal Law Review is the property of Martinus Nijhoff and its content may not be copied or emailed to multiple sites or posted to a listserv without the copyright holder's express written permission. However, users may print, download, or email articles for individual use. 